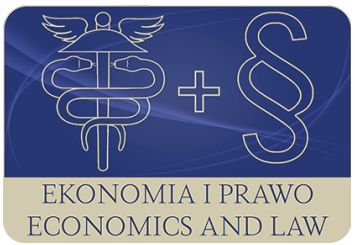

EKONOMIA I PRAWO. ECONOMICS AND LAW Volume 17, Issue 4, December 2018 p-ISSN 1898-2255, e-ISSN 2392-1625

www.economicsandlaw.pl

ORIGINAL ARTICLE

received 02.01.2018; revised 07.06.2018; accepted 31.12.2018

Citation: Grześ-Bukłaho, J. (2018). Intangible assets as a source of competitiveness of real-estate developers. Ekonomia i Prawo. Ecomomics and Law, 17(4): 355-365. doi:10.12775/EiP.2018.026.

\title{
Intangible assets as a source of competitiveness of real-estate developers
}

\author{
JUSTYNA GRZEŚ-BUKEAHO \\ Bialystok University of Technology, Faculty of Engineering Management, Department \\ of Organization and Management, ul. Wiejska 45A, 15-351 Białystok, Poland \\ $\square$ j.grzes@pb.edu.pl
}

\begin{abstract}
Motivation: resources of an enterprise are understood widely and include both tangible means as well as immaterial assets. Currently, there is an increasing emphasis on the importance of intangible resources in building the competitive advantage of an enterprise. Competitive advantage is identified with the status desired by an enterprise, which operates in a competitive environment. It can be defined as a disproportion among enterprises,

which allows one company to compete better than others on the market. The purpose of the analysis is usually therefore to determine the sources of competitive advantage. The knowledge is particularly important for enterprises operating in the property development sector, which is characterized by a considerable volatility resulting from changes in the economic situation in the whole construction sector.

Aim: the purpose of the article is to answer the question of what factors are important in the process of building a competitive advantage of real-estate developers, in particular, what is the role of intangible resources.

Results: conclusions of the analysis made it possible to formulate a summary of intangible assets that contribute most to building a competitive advantage of real-estate developers. These factors were included in several areas, inter alia: enterprise market, relations, finances, product, human resources.
\end{abstract}

Keywords: real-estate developers; residential market; competition; competitive advantage; enterprise resources JEL: L74; M20; R31 


\section{Introduction}

Competition is the primary determinant of the change in the functioning of any company on the market. It determines changes in the way of production, behaviour in the environment; it affects the need to seek modern solutions and their verification on the market (Flak \& Głóg, 2009, p. 30). The consequence of companies competing is therefore an improvement in the quality of goods and services they offer, an increase in the quality of service on the market, a development of technology they use, and maintenance of good relations with their stakeholders.

The mechanism of market competition provides companies with a challenge to meet stakeholder expectations while at the same time interacting with competitors. Studies on competitiveness of enterprises indicate an important role in sectoral studies; other mechanisms will be applicable in the case of service activities, other still in the production or construction.

The subject of the analysis is the specifics of the competitive advantage and the conditions of its achievement, with particular emphasis on the development industry. The main part of the study was devoted to an attempt to identify factors that could contribute to building a competitive advantage, especially intangible assets. The empirical part covers the analysis of factors that may lead to the development of a competitive advantage by real estate developers. The purpose of this part of the study is to answer the question of what factors are crucial in the process of building a competitive advantage of real-estate developers, especially what the role of intangible assets is.

\section{Literature review}

\subsection{Real-estate developers' business activities - theoretical aspect}

The term 'developer' means a natural or legal person who initiates, promotes, commences and conducts a real estate project. Its purpose is to develop space, build new commercial real estate or transform existing ones by creating new property functions (Avril \& Roth, 2001, pp. 13-14).

Property development has a significant impact on the boom in many industries. Its potential is used by manufacturers of construction and finishing materials, subcontractors, service providers, financial institutions, manufacturers of furniture, home appliances and others (Wielgórka, 2012). It is thus a sensitive area that has a potentially significant influence on the economic situation of a given country or region (Baran, 2014).

Development activity is complex, including, beyond just the real estate business, also adaptation processes related to its specific economic, legal, and interest groups (Kucharska-Stasiak, 2006, p. 229). 


\subsection{Intangible assets as a source for competitiveness shaping - theoretical aspect}

The classical theory of economics sees competition as a fundamental mechanism of market economy. Competition is also referred to as rivalry between market participants. Traditional concepts of competitiveness assumed that the main factors of a company's competitiveness in the market were costs, quality, and then differentiation of offers and intensive promotion. It was also recognized that economic agents are not willing to cooperate and adopt a confrontational attitude (Leśniewski, 2015, p. 37).

In the 1960s and 1970s, factors such as low cost and production efficiency gave a company a competitive advantage (scheme 1). At present, they still remain the basis for staying in the market, but they are not sufficient to secure a strong competitive position. Today's winners are characterized not only by cost effectiveness and high internationalization, but also by the ability to develop strategies that ensure the continuity of the innovation process. The importance of communication and building relationships with stakeholders, social and environmental responsibility towards local communities and global society are also underlined.

The importance of intangible assets in building a competitive advantage of enterprises is becoming more and more commonly recognized. Taking into account the different views of intangible assets, we may observe, for example, the classification made by A. Brooking et al. (1998, pp. 115-125), who distinguish such assets as: human, market, organizational (infrastructure) and intellectual property.

Various conceptualizations of intangible assets have been developed over the years, but the most commonly cited in the relevant literature is the classification based on three important components: human capital, structural capital and relational capital (see: Bontis (1998, pp. 63-76); Goh (2000, pp. 115-119)). Human capital covers all the individual capabilities, knowledge, skills and experience of employees and managers of the organization (Edvinsson \& Malone, 2001). Structural capital arises from the processes and organizational values, reflecting the company's external and internal focus, and its future development (Bontis et al., 2000, pp. 85-100). Relational capital is an ingredient present in relations and social networks. It consists of internal social capital and external social capital. It includes, among others., relationships with customers, suppliers and competitors, business alliances, brands (Bozzolan et al., 2003, pp. 543-558; Dzinkowski, 2000, pp. 32-36).

Intangible assets meets the criteria set by J. Barney (1991, pp. 105-106), whose opinion is that the resources that would be a source of competitive advantage for an enterprise, and the creation of effective competitive instruments, should be: valuable, unique, difficult to imitate, and impossible to substitute with any other resources, and therefore being non-replaceable or difficult to replace by other resources. 
Intangible assets creates an invisible business resource that generates visible effects. It is connected to the experience and knowledge of employees, customer relationships, and the procedures and technologies used in the organization. Among theorists and practitioners, there is no consistency in the definitions, universal valuation methods, depreciation methods, reporting capabilities in financial reports, etc. It is also possible to observe the use of similar terms, such as intellectual capital, intangible assets, intangible resources, intangible factors. This is due to the fact that the subject of the analysis are phenomena and elements that are not physical and therefore difficult to describe (Urbanek, 2008, pp. 31-32).

When analyzing the subject matter literature, it is difficult to point out the difference between intangible assets and intellectual capital. Many authors, such as B. Lev (2001), treat intangible assets and intellectual capital interchangeably as a non-physical source of business value. Also the classification created under the direction of K.E. Sveibye (1997), within the so-called Konrad Group, identifies intangible resources with intellectual capital, pointing to these three components:

- competence of employees (education, experience, values and social skills, attitude towards the organization);

- internal structure of an organization (patents, licenses, concepts, processes, know-how, trademarks, organizational culture, information technology, administrative systems);

- external organizational structure (relations with customers and suppliers, reputation, brand, image, trademarks).

J. Low and P.C. Kalafut (2004, pp. 57-185), based on their own research and on other authors, identified twelve major groups of intangible assets, including: leadership, strategy execution, communication and disclosure, brand value, reputation, networks and alliances, technology and processes, human capital, organization and workplace culture, innovation, intellectual capital and flexibility. The authors point out that the list compiled by them is longer than analogous ones developed by other authors. This is due to the importance of all groups, as well as the fact that specific industries are significantly different from one another and that the weight of particular intangible assets may be different for them.

\subsection{Cause and effect relations in competitiveness of enterprises}

Competitiveness, as a complex structure, is presented in the relevant literature with numerous schemes. The analysis of competitiveness concepts proves that it is helpful to build a logical structure that determines competitiveness and the relationships between its components. This author developed a model (scheme 2) taking into account the following components of the competitiveness of real-estate developers: sources of competitiveness, the resources and competencies of an enterprise, the key resources and competences of an enterprise (key 
success factors), competitive advantage and competitive position. The model's assumption is that competitiveness means the ability of an enterprise to exist and grow on the market, and the pursuit of a competitive advantage.

It is generally accepted that competitive advantage, or competitive ability, means a better positioning of a company on the market in relation to its competitors. At the same time, the pursuit of businesses and their competitors to gain competitive advantage is one of the most important forces that contributes to the development of competition, motivates the agents to an increasing intensification of their competitive processes (Leśniewski, 2015, p. 36).

Referring to the resource approach, M. Seifert and A.L. Hadida (2006, p. 791), explain the essence of competitive advantage in a unique combination of resources, competence and abilities. At that, resources constitute a contribution to the manufacturing process, competence is the combination of employee knowledge and machine potential in the process of value creation, while abilities are a skillful composition of productive factors that leads to the achievement of competitive advantage.

An impact on the functioning of a company comes from its environment, in particular the immediate (market) environment. A company in turn also influences other market players. An enterprise, based on an environmental analysis and formulated objectives, selects its resources and competences. This allows for an identification of key resources and competences (key success factors). The sources of competitiveness are thus identified with enterprise resources, which are its competitive potential. Their formation and management is carried out by a company, while the competitive advantage and competitive position are the effect expressed respective to the competitors in the market environment. Thus, an advantage over competitors is when an enterprise, using its own resources and expertise, is able to deliver a product/service that satisfies the needs of potential buyers in a way that is unique enough for the market to choose from rather than offerings of its competitors. A competitive advantage means we are better than our competitors. According to the presented concept, a company's competitive position results from the competitive advantage achieved (GrześBukłaho, 2015, pp. 95-97).

In the opinion of this author, achieving a lasting advantage in a competitive market is not possible, since it requires a company to be constantly exceeding its current status, to constantly seek to strengthen its position on the market. The concept of sustainable competitive advantage is increasingly being questioned. This is due to the dynamically changing market conditions and the emergence of hyper-competition. As a result, a competitive advantage is increasingly provisional (D’Aveni et al., 2010, pp. 1371-1385).

\section{Methods}

The analysis of secondary sources was verified by empirical studies. The analysis used a graphic model, developed by the author, to form one's reputation 
in the process of building a competitive advantage of real-estate developers. The model was created based on the conducted research. The first stage of the survey was a questionnaire survey with an aim to assess the reputation of developers. The survey was addressed to customers of developer companies and housing cooperatives who purchased an apartment on the primary market of the Podlaskie voivodeship in 2005-2011. The subject of the research conducted by the author were apartments in multifamily buildings. The time period chosen was used to analyze causal relationships both during the boom times in the construction industry and during downturn cycles that occurred during the period analyzed. This made it possible to generalize the results of the research. In the feedback process, nearly 400 questionnaires were received, 361 of which were questionnaires properly filled and accounted for the analyzed research sample. The sample selection at this stage of the study was arbitrary on the basis of the knowledge of real estate completed for use by developers in the analyzed period.

Stage II was to conduct a study on the essence and importance of reputation in the process of shaping a competitive advantage of real-estate developers with the method of the experts' panel. The survey was aimed at selected people associated with the real estate development industry, who are experts in their fields. A group of 10 experts involved directly or indirectly in the real estate industry participated in the panel. Among the experts were representatives of developers ( 2 people), representatives of the media ( 2 people), real estate owners (l person), bankers/financial analysts ( 2 people), business people (1 person), architects (designers of housing construction -1 person), representatives of the academic community dealing with construction issues (1 person).

Based on empirical studies conducted among the clients of chosen real-estate developers, as well as within the panel of experts, some factors determining the reputation of a real-estate development company were determined and analyzed. In the first stage, 22 such factors were specified and identified under the term of critical factors in building a reputation. Then, an attempt was made to limit the number of factors by prioritising them. As a result, the factors that strongly affect a company's reputation include: a company's experience, relations with customer/customer service level, relationships with suppliers and subcontractors, quality of workmanship, timely implementation and active advertising policy. Based on the expert assessment of the importance of the listed factors in building a competitive advantage of real-estate developers, critical success factors were distinguished. The key factors of success were those rated as at least valid, i.e. their arithmetic average was 4.0 and above. Such assessment was given to 23 factors out of the 31 analyzed ones. In order to ensure the legibility of the built model, an attempt was made to limit the list of factors leading to the achievement of a competitive advantage by grouping them. Specific assumptions were made at that.

Based on the results of the research, a graphical model of forming a reputation has been developed to allow for a competitive advantage by a developer 
in a dynamically changing environment. The model has been verified through multiple case studies.

\section{Results}

The research tasks described in Methods were the basis for the construction of copyright theoretical model of shaping the reputation in the process of building a competitive advantage of real-estate developers (scheme 3 ). The model assumes the causal relationship of all the major mechanisms of competitive advantage. The model focuses on the most important elements of the target (Grześ-Bukłaho, 2015, pp. 236-238).

\section{Conclusion}

The author's analysis of secondary materials and empirical studies, based on which a graphical reputation model has been developed for the process of building a competitive advantage for real-estate developers, show that intangible assets are fundamental to the successful functioning of the market. The real estate industry is characterized by considerable variability resulting from the boom in the entire construction sector. The impact of developers on the market cannot, therefore, be limited solely to current sales stimulation, but should be regular and continuous, in order to create a positive and trustworthy reputation for a company.

The analysis of the factors that contribute to a competitive advantage of real-estate developers allows us to share the views expressed by many authors that the assets of intellectual capital are considered to be critical (Barney, 2001, pp. 643-650; Grant, 2002, pp. 133-48).

Based on the discussion in the article on real-estate developers and the developed model illustrating the process of building a competitive advantage of real-estate developers, it is important to recognize that relational capital plays a key role in the construction industry for the relevant companies and is developed primarily by them. It can be assumed that relational capital is linked both to the need to build good relationships with subcontractors, suppliers, banks, media, etc., but also with current and potential customers. The obtained results are consistent to a point with the theoreticians' views on the growing importance of intangible assets for building a competitive advantage of companies.

In addition, the analysis of the graphical model indicates that the main factors of competitive advantage of real-estate developers are also included in the areas of: company functioning, product, financial and price policy, which results from the specificity of the offered product namely an apartment.

Analyzing the competitiveness of real estate developers based on intangible assets will certainly require a further successive verification by researchers, taking into account the changes in the targeted and general environment. It also seems right to extend the research into the whole country. A comparison, 
in particular, of national companies with foreign capital and those operating on local markets.

\section{References}

Archibugi, D., \& Lundvall, B. (Eds.). (2001). The globalizing learning economy. Oxford: Oxford University Press.

Avril, B., \& Roth, B. (2001). La promotion immobiliere. Construire pour autrui. Paris: Pressem de l'Ecole Nationale des Ponts et Chaussees.

Baran, M. (2014). Skuteczność utrzymywania przewagi konkurencyjnej przez liderów branży budowlanej w świetle kryzysu w otoczeniu gospodarczym. In M. Baran (Ed.), Poszukiwanie przewagi konkurencyjnej wybrane uwarunkowania. Kraków: UJ.

Barney, J. (1991). Firm resources and sustained competitive advantage. Journal of Management, 17(1). doi:10.1177/014920639101700108.

Barney, J. (2001). Resource-based theories of competitive advantage: a tenyear retrospective on the resource-based view. Journal of Management, 27(6). doi:10.1177/014920630102700602.

Bontis, N.(1998). Intellectual capital: an exploratorystudy that develops measures and models. Management Decision, 36(2). doi:10.1108/00251749810204142.

Bontis, N., Keow, W., \& Richardson, S. (2000). Intellectual capital and business performance in Malaysian industries. Journal of Intellectual Capital, 1(1). doi:10.1108/14691930010324188.

Bozzolan, S., Favotto, F., \& Ricceri, F. (2003). Italian annual intellectual capital disclosure: an empirical analysis. Journal of Intellectual Capital, 4(4). doi:10.1108/14691930310504554.

Brooking, A., Board, P., \& Jones, S. (1998). The predictive potential of intellectual capital. International Journal of Technology Management, 16(1-3). doi:10.1504/IJTM.1998.002646.

D'Aveni, R., Dagnino, G., \& Smith, K., (2010). The age of temporary advantage. Strategic Management Journal, 31(13). doi:10.1002/smj.897.

Dzinkowski, R., (2000). The measurement and management of intellectual capital: an introduction. Management Accounting, 78(2).

Edvinsson, L., \& Malone, M.S. (2001). Kapitat intelektualny. Poznaj prawdziwa wartość swojego przedsiębiorstwa odnajdując jego ukryta wartość. Warszawa: PWN.

Flak, O., \& Głóg, G. (2009). Konkurencyjność przedsiębiorstwa: pojęcia, definicje, modele. Katowice: AE w Katowicach.

Goh, T., (2000). Intellectual capital: the new wealth of organizations. Personnel Review, 29(1). doi:10.1108/pr.2000.29.1.115.1.

Grant, R. (2002). The knowledge-based view of the firm. In C. Choo, \& N. Bontis (Eds.), The strategic management of intellectual capital and organizational knowledge. New York: Oxford University Press. 
Grześ-Bukłaho, J. (2015). Ksztaltowanie reputacji w procesie budowania przewagi konkurencyjnej przedsiębiorstw deweloperskich: podstawy teoretyczne $i$ wyniki badań empirycznych. Białystok: Oficyna Wydawnicza Politechniki Białostockiej.

Kucharska-Stasiak, E. (2006). Nieruchomość w gospodarce rynkowej. Warszawa: PWN.

Leśniewski, M.A. (2015). Konkurencyjność miękka przedsiębiorstw. Warszawa: Difin.

Lev, B. (2001). Intangible: management, measurement, and reporting. Washington: Brooking Institution Press.

Low, J., \& Kalafut, P.C. (2004). Niematerialna wartość firmy: ukryte źródta przewagi konkurencyjnej. Kraków: Oficyna Ekonomiczna.

Seifert, M., \&Hadida, A.L.(2006). Facilitatingtalentselectiondecisionsinthemusic industry. Management Decision, 44(6). doi:10.1108/00251740610673341.

Sveiby, K.E. (1997). The intangible asset monitor. Journal of Human Resources Costing and Accounting, 2(1). doi:10.1108/eb029036.

Urbanek, G. (2008). Wycena aktywów niematerialnych przedsiębiorstwa. Warszawa: PWE.

Wielgórka, D. (2012). Value management company in turbulent environment. Prague: Publish House Education and Science.

\section{Acknowledgements}

Author contributions: author has given an approval to the final version of the article.

Funding: this research was undertaken as part of the Methods of solving contemporary problems in organization management project and was fully funded by a grant (S/WZ/3/2015).

Note: the results of this study were presented at 9th International Conference on Applied Economics Contemporary Issues in Economy (June 22-23, Torun, Poland). 


\section{Appendix}

\section{Scheme 1 .}

\section{The pyramid of competitiveness of enterprises since the 1960s}

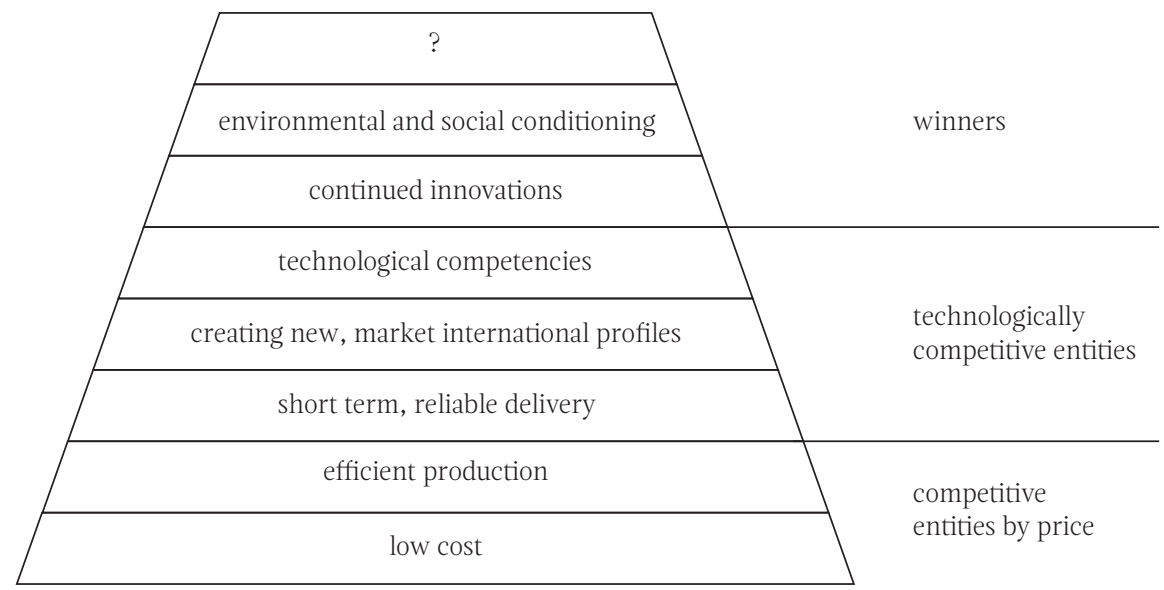

Source: Archibugi and Lundvall (2001, p. 255).

\section{Scheme 2.}

The competitive model of a real-estate developer

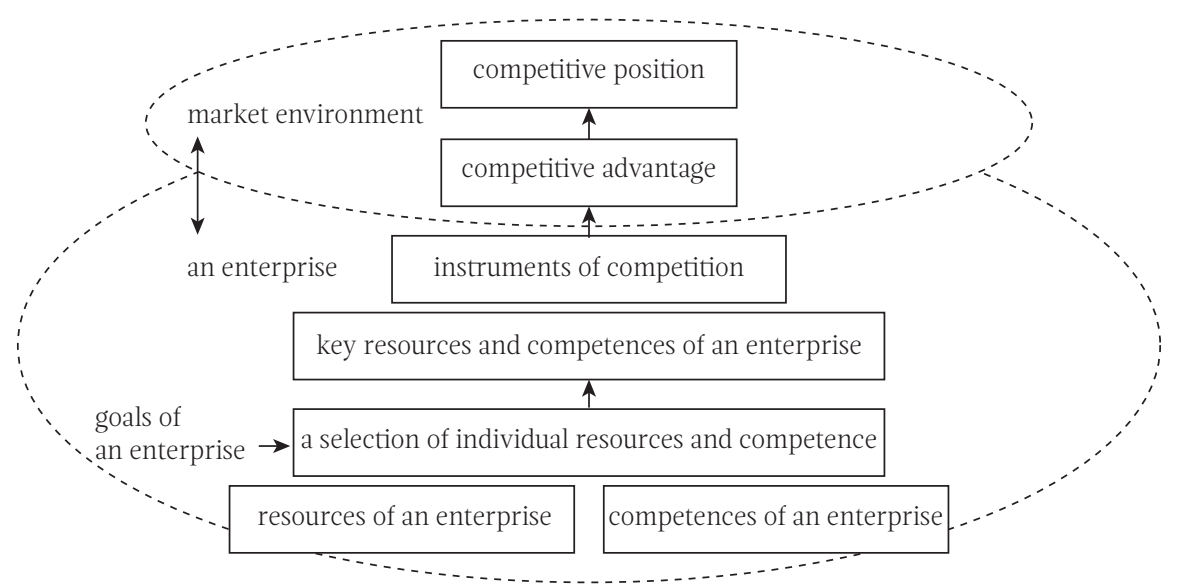

Source: Own preparation based on the analysis of relevant literature. 


\section{Scheme 3 .}

The competitive model of a real-estate developer

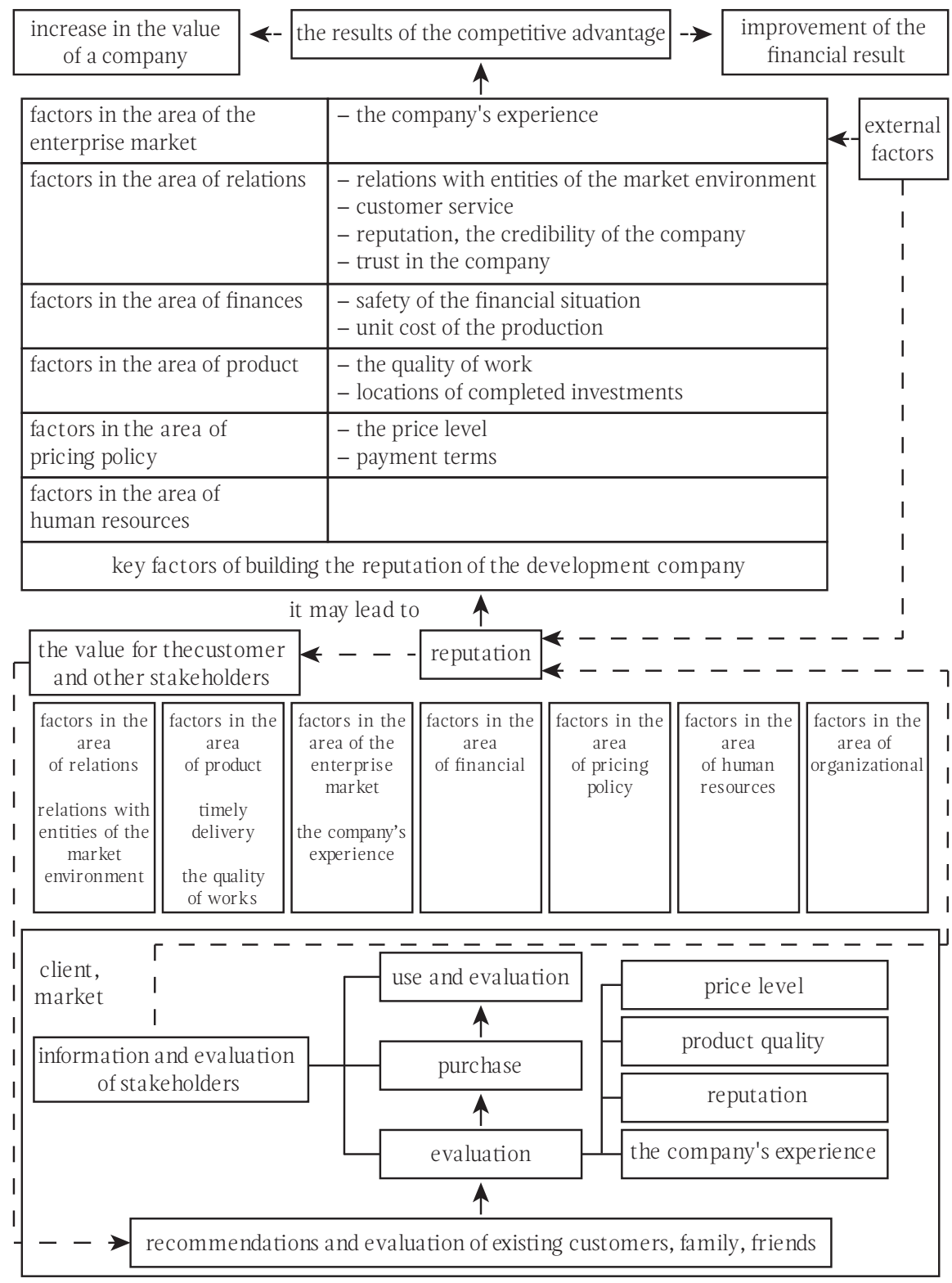

Source: Own preparation based on the results of research. 
